\title{
Gadget for Epilithic Microalgal Sampling (GEMS)
}

\author{
Canani, $L G C$. $^{\text {** }}$,Torgan, $L C$. $^{\mathrm{b}}$ and Menezes, $M{ }^{\mathrm{c}}$ \\ aPrograma de Pós-Graduação em Botânica, \\ Universidade Federal do Rio Grande do Sul - UFRS, \\ R. Affonso Sanmartin, 94, casa 03, Bairro Jardim do Salso, 91410-100, Porto Alegre, RS, Brazil

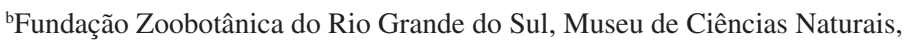 \\ Av. Salvador França 1427, CEP 90690-000, Porto Alegre, RS, Brazil \\ ${ }^{\mathrm{c}}$ Museu Nacional, Universidade Federal do Rio de Janeiro - UFRJ, \\ Quinta da Boa Vista, São Cristóvão, Rio de Janeiro, RJ, Brazil \\ *e-mail: lgustavocc@gmail.com \\ Received November 24, 2008 - Accepted January 27, 2009 - Distributed May 31, 2010
}

(With 2 figures)

\begin{abstract}
Benthic microalgae sampling in lotic systems is carried out using either artificial or natural substrate. Natural substrate is more suitable for biomass and productivity estimates as well as biodiversity assessment because it contains the communities that are typical of the environment. We present a new gadget for epilithic microalgae sampling (GEMS) that allows sampling in situ when it is impossible to remove the substrate from the river bed. The sampler consists of an acrylic box with a $25 \mathrm{~cm}$ diameter opening on its base that allows access to the substrate. This gadget can be used in shallow plan bedrock streams and it keeps the sample area isolated as much as possible minimising losses and contamination. It is also easy to construct and handle.
\end{abstract}

Keywords: sampling, stream, epilithon.

\section{Dispositivo para amostragem de microalgas epilíticas}

\section{Resumo}

As amostragens de microalgas bênticas em sistemas lóticos são realizadas através do uso de substrato natural ou artificial. Substratos naturais são mais adequados para a estimativa de biomassa e produtividade, assim como, para a avaliação de biodiversidade, porque eles contêm as comunidades que são típicas de um determinado ambiente. Nós apresentamos um novo dispositivo para amostragem de microalgas epilíticas (GEMS) que permite a amostragem in situ, quando é impossível remover o substrato do leito do rio. O amostrador consiste em uma caixa de acrílico com uma abertura de $25 \mathrm{~cm}$ de diâmetro em sua base que permite acesso ao substrato. $\mathrm{O}$ amostrador pode ser usado em riachos rasos e de leito rochoso e plano, e mantém a área amostral o mais isolada possível, minimizando perdas e contaminação, além de ser fácil de construir e manusear.

Palavras-chave: amostragem, riacho, epilíton.

\section{Introduction}

Benthic cyanobacteria and algae (especially diatoms) are the main primary producers in streams and rivers (Biggs, 1996). In these fast flowing water environments, plankton is rare so that benthic algae have an important role in such aquatic foodwebs.

Benthic microalgae sampling in lotic system is usually carried out using either artificial substrate (e.g., glass slides, plastic and acrylic plates, or clay tiles) (Ghosh and Gaur, 1998; Stevenson and Bahls, 1999) or natural substrate (pebbles, cobbles, sediment, macroalgae or macrophytes) from the river bed (Round, 1993; Tolotti, 2001; Sala et al., 2002; Cetto et al., 2004; Ludwig et al.,
2004; Landucci and Ludwig, 2005; Ferrari and Ludwig, 2007; Salomoni et al., 2007).

The use of artificial substrate reduces effort and analysis time (e.g. slides can be directly observed in a microscope), though it requires an extra trip to deploy the substrate. It causes less habitat disruption, and substantially improves sampling precision, though problems such as substrate loss and/or damage, mainly due to theft and vandalism may occur (Lane et al., 2003). Artificial substrate should be used in succession studies, when natural substrate varies among sites or in comparisons of environmental variables, but it should 
be avoided in biomass and productivity estimations (Aloi, 1990).

Natural substrate is more recommended for benthic algae floristic studies because it will contain the communities that are typical of the environment. The substrate characteristics such as chemical composition, porosity, crystal size and shape, among others, influences algal colonisation (Burkholder, 1996).

Epilithon sampling is usually carried out by withdrawal of pebbles and rocks (preferably flat ones) from the riverbed, stream or lake. When it is impossible to remove the substrate from the river bed (big rock blocks, bedrock streams) the sample collection must be made in situ, which leads to some technical difficulties: the scrapped material is swept away by the water current and the incoming of allochthonous material contaminates the sample area.

Aloi (1990) in the review about periphyton field methods recommended the use of brushing syringe-samplers, created by Stockner and Armstrong (1971) and modified by Loeb (1981), due to their low cost, ease of use and efficiency in removal of periphyton from firm substrate. Recently, Peters et al. (2005) improved a brush sampler based on Loeb (op. cit). These samplers remove periphyton from a limited area ( 3.14 and $5.7 \mathrm{~cm}^{2}$ respectively). Considering these factors our purpose was to develop the gadget for epilithic microalgal sampling (GEMS), which has a bigger sampling area, and it is easy to construct and handle, to be used in shallow (up to $30 \mathrm{~cm}$ depth) bedrock stream, where benthic microalgae are found.

\section{Gadget for Epilithic Microalgae Sampling (GEMS)}

The Gadget for Epilithic Microalgae Sampling (GEMS) consists of an acrylic box $50 \mathrm{~cm}$ high. The side to be in contact with the riverbed has a $25 \mathrm{~cm}$ diameter opening (490.87 $\mathrm{cm}^{2}$, the size of the quadrat) and the opposite face is opened to allow access inside the box. The box surface that will be in contact with the rock is covered with two centimetres of soft rubber in order to allow adhesion of the sampler on the wet and/or submerged rocky surface. The rubber material that covers the basis of the sampler can vary in terms of density, softness and thickness to give the best adherence possible to the rocky surface and thus prevents the entry of water through irregularities of the surface (Figure 1). Once placed on the desired area, the equipment avoids water running over the substrate which will be sampled. The water remaining in the sampler is removed and then the surface is scraped with a brush. The dislodged material is then collected using a syringe or pipette.

\section{The GEMS Advantages}

The GEMS has some technical advantages such as: 1) it allows direct access to submerged epilithon in situ with effective isolation of the sampling area; 2) it dimin- ishes losses during sampling; 3) it prevents the entrance of allochthonous particles; 4) it optimises the sampling time using a great portion of substrate at a time; and 5) it estimates the taxa densities due to the use of the known area.

In relation to its use and handling, the acrylic constitution of the GEMS makes it virtually unbreakable, which is desirable for field work. Sampling can be done by one person by keeping the gadget fixed to the substrate by stepping on its base so that the hands are free to scrape and pump off, but with two people it is even faster and easier: one keeps the GEMS in the selected position and the other one does the scraping (Figure 2).

The GEMS was used for the first time in research on the floristic composition and density of diatoms in a bedrock stream, Salto River, in Ibitipoca State Park, in the state of Minas Gerais, Brazil (Canani, 2005).

As improvements for this gadget we suggest the following: 1) the reduction of the circumference of the base, resulting in the reduction of size and weight of the gadget; 2) the search for different materials to improve the adherence of GEMS to the substrate; and 3) a system to integrate the scraping and pumping in the sampler box.

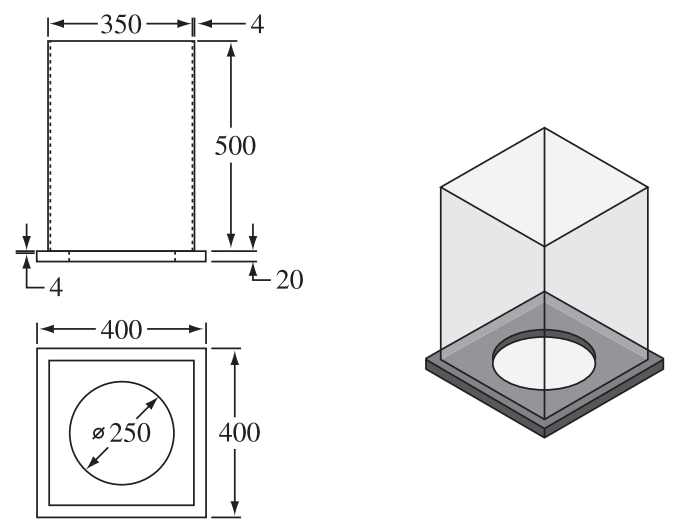

Figure 1. Gadget for Epilithic Microalgae Sampling (GEMS) model (dimensions in millimetres).

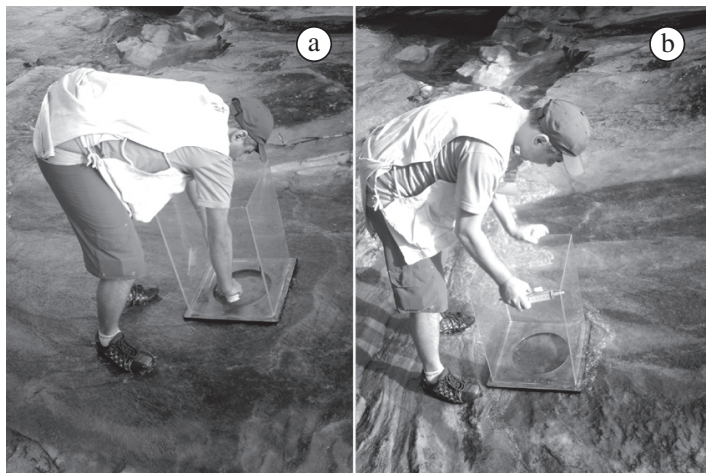

Figure 2. Sampling on a bedrock shallow stream, Salto River, Minas Gerais, Brazil. 
Acknowledgements - The authors thank the Conselho Nacional de Desenvolvimento Científico e Tecnológico (CNPq) for the financial support (Grants 133831/2003-5 and 302102/2007-8). We also thank the anonymous reviewers for their constructive remarks.

\section{References}

ALOI, JE., 1990. A critical review of recent freshwater periphyton field methods. Canadian Journal of Fisheries and Aquatic Sciences, vol. 47, p. 656-670.

BIGGS, BJF., 1996. Patterns in Benthic Algae of Streams. In STEVENSON, RJ., BOTHWELL, ML. and LOWE, RL. (Eds.). Algal Ecology, Freshwater Benthic Ecosystems. San Diego: Academic Press. p. 31-53.

BURKHOLDER, JM., 1996. Interactions of Benthic Algae with Their Substrate. In STEVENSON, J., BOTHWELL, ML. and LOWE, RL. (Eds.). Algal Ecology, Freshwater Benthic Ecosystems. San Diego: Academic Press. p. 253-297.

CANANI, LGC., 2005. Flora e distribuição das diatomáceas (Bacillariophyta) epilíticas do Rio do Salto, Parque Estadual do Ibitipoca, $M G$. Rio de Janeiro: Universidade Federal do Rio de Janeiro. 67 p. [Dissertação de Mestrado]

CETTO, JM., LEANDRINI, JA., FELISBERTO, SA. and RODRIGUES, L., 2004. Comunidade de algas perifíticas no reservatório de Irai, Estado do Paraná, Brasil. Acta Scientiarum. Biological Sciences, vol. 26, no. 1, p. 1-7.

FERRARI, FR. and LUDWIG, TAV., 2007. Coscinodiscophyceae, Fragilariophyceae e Bacillariophyceae (Achnanthales) dos rios Ivaí, São João e dos Patos, bacia hidrográfica do rio Ivaí, município de Prudentópolis, PR, Brasil. Acta Botanica Brasilica, vol. 21, no. 2, p. 421-441. GHOSH, M. and GAUR, JP., 1998. Current velocity and the establishment of stream algal periphyton communities. Aquatic Botany, vol. 60, no. 1, p. 1-10.

LANDUCCI, M. and LUDWIG, TAV., 2005. Diatomáceas de rios da bacia hidrográfica Litorânea, PR, Brasil: Coscinodiscophyceae e Fragilariophyceae. Acta Botanica Brasilica, vol. 19, no. 2, p. 345-357.
LANE, CM., TAFFS, KH. and CORFIELD, JL., 2003. A comparison of diatom community structure on natural and artificial substrate. Hydrobiologia, vol. 493, no. 1-3, p. 65-79.

LOEB, SL., 1981. An in situ method for measuring primary productivity and standing crop of the epilithic periphyton community in lentic systems. Limnology and Oceanography, vol. 26, p. 394-399.

LUDWIG, TAV., FLORES, TL., MOREIRA FILHO, H. and VEIGA, LAS., 2004. Inventário florístico das diatomáceas (Ochrophyta) de lagoas do Sistema Hidrológico do Taim, Rio Grande do Sul, Brasil: Coscinodiscophyceae. Iheringia, Série Botânica, vol. 59, no. 1, p. 97-106.

ROUND, FE., 1993. A review and methods for the use of epilithic diatoms for detecting and monitoring changes in river quality. London: HMSO. 65 p.

SALA, SE., DUQUE, SR., NUNES-AVELLANEDA, M. and LAMARO, AA., 2002. Diatoms from Colombian Amazon: some species of the genus Eunotia (Bacillariophyceae). Acta Amazonica, vol. 32, no. 4, p. 589-603.

SALOMONI, SE., TORGAN, LC. and ROCHA, O., 2007. Sampler collection gadget for epilithic diatoms. Revista Brasileira de Biologia = Brazilian Journal of Biology, vol. 67, no. 4, p. 631-637.

STEVENSON, RJ. and BAHLS, LL., 1999. Periphyton Protocols. In BARBOUR, MT., GERRITSEN, J., SNYDER, BD. and STRIBLING, JB. Rapid bioassessment protocols for use in streams and wadeable rivers: periphyton, benthic macroinvertebrates and fish. 2 ed. Washington: Environmental Protection Agency. (Office of Water, chapter 6)

STOCKNER, JG. and ARMSTRONG, FAJ., 1971. Periphyton of the experimental lakes area, northwestern Ontario. Journal of the Fisheries Research Board of Canada, vol. 28, p. 215-229.

TOLOTTI, M., 2001. Phytoplankton and littoral epilithic diatoms in high mountain lakes of the Adamello-Brenta Regional Park (Trentino, Italy) and their relation to trophic status and acidification risk. Journal of Limnology, vol. 60, no. 2, p. 171-188. 
